\title{
Antioxidant potential and low-density lipoprotein cholesterol (LDL-c) uptake of the black seed and honey mixture on human hepatocellular carcinoma (HepG2) cells
}

\author{
${ }^{1}$ Mohd Isa, N.S., ${ }^{1}$ Ng, J.S., ${ }^{1}$ Tufail Ahmad, F., ${ }^{2}$ Kassim, M.N.I., ${ }^{3}$ Norhayati, H. and \\ $1,2,{ }^{*}$ Yusof, H.M. \\ ${ }^{1}$ Faculty of Fisheries and Food Science, Universiti Malaysia Terengganu, 21030 Kuala Nerus, Terengganu, \\ Malaysia. \\ ${ }^{2}$ Institute Marine Biotechnology, Universiti Malaysia Terengganu, 21030 Kuala Nerus, Terengganu, \\ Malaysia. \\ ${ }^{3}$ Faculty of Health Science, Universiti Sultan Zainal Abidin, Gong Badak, 21300 Kuala Nerus, Terengganu, \\ Malaysia
}

\section{Article history:}

Received: 14 December 2020

Received in revised form: 29

March 2021

Accepted: 22 May 2021

Available Online: 5

December 2021

\section{Keywords:}

Hepatocellular carcinoma (HepG2) cells,

Black seed,

Honey,

LDL-c uptake,

Antioxidant,

Cell cytotoxicity

DOI:

https://doi.org/10.26656/fr.2017.5(6).730

\begin{abstract}
High lipid levels especially low-density-lipoprotein cholesterol (LDL-c) are associated with increased risk of cardiovascular (CVD) and coronary heart disease (CHD). Both black seed (Nigella sativa L.) and honey are well-known in the hypolipidemic potential and have CVD protective effects. In the present study, LDL-c uptake of the black seed and honey mixture was tested on HepG2 cells. Antioxidant activities of black seed and honey mixtures were determined through the 2, 2'-diphenyl-1-picrylhydrazyl (DPPH) assay. The anticancer potential of black seed and honey mixtures in HepG2 cells was performed using 3-(4,5-dimethylthiazol-2-yl)-2,5-diphenyltetrazolium bromide (MTT) cytotoxicity assay. Black seed possessed the highest antioxidant activities with $\mathrm{EC}_{50} 6.54 \mathrm{mg} / \mathrm{mL}$ as compared to honey with $\mathrm{EC}_{50}$ value $9.56 \mathrm{mg} / \mathrm{mL}$ while the black seed and honey mixture have $\mathrm{EC}_{50}$ between black seed and honey. From the results obtained, no synergistic effect was observed in the mixtures as the $\mathrm{EC}_{50}$ values were within the range of black seed and honey. Furthermore, no significant difference ( $p>0.05)$ among ratios (1:1, 2:1 and 1:2). However, the decrease in cell proliferation was the highest in black seed and honey mixture at 1:1 ratio $(\mathrm{p}<0.05)$ than individually treated black seed and honey. Thus, the black seed and honey mixture at ratio 1:1 was the most potent anticancer agent with an $\mathrm{IC}_{50}$ value of $7.44 \mu \mathrm{g} / \mathrm{mL}$. The present study illustrated that black seed and honey mixtures possess a lipid-lowering effect via LDL-c uptake in HepG2 cells $(p<0.05)$. The highest LDL-c uptake was observed at $15 \mu \mathrm{g} / \mathrm{mL}$ with the treatment of black seed and honey mixture at $1: 2$ ratio which was $294.4 \%$. Further studies should be conducted on primary human liver cells to further justify the correlation between the antioxidant level and LDL$\mathrm{c}$ uptake mechanism of black seed and honey mixtures.
\end{abstract}

\section{Introduction}

Hyperlipidaemia is a condition characterized by an abnormal elevation in one or more of the serum lipids such as total cholesterol, low-density lipoprotein cholesterol (LDL-c) and triglycerides (Shinde et al., 2013). Hypercholesterolemia is the main risk factor for cardiovascular diseases such as ischaemic heart disease and ischemic stroke. Elevated LDL-c is a risk factor for the development of cardiovascular disease. Recently, the role of antioxidants in plant-derived foods were studied in relation to human health. A previous study reported the beneficial effect of fruits and vegetables rich diets with a protective effect against chronic diseases including CVD (Wang et al., 2014) due to the medicinal compound in the plant (Saman et al., 2010).

There are several forms of cholesterol-lowering drugs used to treat hypercholesterolemia. These drugs can be associated with side effects. One of the most popular cholesterol-lowering drugs, statin, has been shown to contribute to symptoms of intolerance or even adverse side effects such as myopathy, hepatotoxicity, neurological effects and diabetes mellitus (Wilkinson et 
al., 2014). In addition, cancer chemotherapy is associated with fatigue, pain, diarrhoea, nausea and vomiting, sores in the mouth and throat, loss of appetite, hair loss and several others (Lorusso et al., 2017). As a result, many people today prefer natural herbs or plants to replace their medication since herbal therapies have fewer side effects as compared to prescription drugs.

Previous studies reported that both black seed and honey are effective in lowering the serum LDL-c, possess high antioxidant activity and are effective against cancer cells (Majid et al., 2013; Shafiq et al., 2014; Sahebkar et al., 2016). Nigella sativa, from the family Ranunculaceae, which is also known as black seed consists of several bioactive compounds such as thymoquinone, $\alpha$-hederin, alkaloids, flavonoids, antioxidants, fatty acids and many others (Sultan et al., 2015). There is evidence that shows that consumption of black seed can significantly decrease LDL-c in the blood (Asgary et al., 2013; Sahebkar et al., 2016) apart from total cholesterol and triglycerides lowering. Recently, Rashidmayvan et al. (2019) reported that N.sativa seed oil supplements exhibited benefits on serum liver enzymes and lipid profile in non-alcoholic fatty liver disease (NAFLD) patients. The hypocholesterolemic effect of black seed is due to the presence of bioactive compounds that can help to lower serum cholesterol such as phytochemicals, antioxidants and unsaturated fatty acids (Sahebkar et al., 2016) including monounsaturated oleic acid, polyunsaturated omega- 6 linoleic acid and omega-3 linolenic acid. Besides, the major bioactive compound thymoquinone and its dimer dithymoquinone, thymohydroquinone, and thymol in black seed also have an anti-cancer effect (Shafiq et al., 2014). These compounds possess cytotoxicity activity against a few human cancer cell lines such as HepG2 cells, and also colon, breast and lung cancers (Shafiq et al., 2014). Honey, on the other hand, has beneficial therapeutic components that are also related to its antioxidant properties. Polyphenol compounds such as phenolic acid and flavonoids, rather than enzymes (peroxidase, catalase), vitamins and mineral trace elements are known to be responsible for this action (Gheldof et al., 2002).

Studies proved that consumption of honey can reduce LDL-c in serum (Majid et al., 2013; Wan Ghazali and Mohamed, 2015). Extensive studies have shown that honey is effective against cancer cells including HepG2 cells. A study reported that honey exhibits its cytotoxic effects against HepG2 cells through reduction of expression of the B-cell lymphoma 2 (Bcl-2) gene which leads to apoptosis (Sadeghi-Aliabadi et al., 2015). The anti-cancer properties of honey are contributed by its flavonoids and phenolic content (Erejuwa et al., 2014).
One of the functions of the liver is to maintain an individual cholesterol balance by controlling the concentration of LDL-c in the plasma. The concentration of cholesterol can affect the function of the low-density lipoprotein receptor (LDLR) in the liver. LDLR is responsible for mediating the intake of LDL plasma by endocytosis regulated by the receptor and cholesterol in cells used (Goldstein and Brown, 2009). Cancer refers to the uncontrolled growth of cells that display malignant conduct. The abnormal cells expand quickly outside their natural limits and then spread to neighbouring body parts and other organs. Some of the common death from cancer are lung, liver, stomach, colorectal, breast and oesophagus (Stewart and Wild, 2015). Hepatocellular carcinoma (HCC) is also known as primary hepatic cancer. It's one of the world's most common cancer. Persistent Hepatitis B (HBV) or Hepatitis C (HCV) infections are the major risk factors for HCC. Other risk factors include aflatoxin exposure from Aspergillus fungi, alcohol, smoking, overweight, diabetes, family factors as well as dietary factors such as high intake of meat and high glycemic load (Bosetti et al., 2004). HepG2 is one of the common HCC forms.

Since previous studies reported that both black seed and honey are effective in lowering the serum LDL-c, possess high antioxidant activity and are effective against cancer cells, it is, therefore, important to discover and develop a natural product from foods that has multiple effects in cholesterol-lowering through the increase of LDL-c uptake in liver and antioxidant activities. However, the exact mechanisms responsible for cholesterol-lowering are not established because there are a few mechanisms responsible for cholesterollowering such as LDL-c uptake, reduction of LDL-c synthesis and reduction of LDL-c absorption. In addition, several studies have documented that the combination of black seed and honey may improve health problems such as functional dyspepsia and asthma (Mohtashami et al., 2015; Koshak et al., 2017). Furthermore, according to Hassan et al. (2012), both black seed and honey are effective against HepG2 cells but further studies should be performed on the impact of their mixtures on HepG2 cells. Besides, HepG2 cells are chosen in this study because they still exhibit multiple hepatic roles, including those linked to cholesterol and triglyceride metabolism (Donato et al., 2015). Thus, in the present study, the black seed and honey mixtures will be used to determine their effects on lowering LDL-c, antioxidant activity and its anti-cancer properties.

\section{Materials and methods}

2.1 Samples

Human Hepatocellular Carcinoma (HepG2) cells 
were obtained from the Institute of Marine Biotechnology (IMB) Laboratory, Universiti Malaysia Terengganu (UMT). Eagle's minimal essential medium (EMEM) supplement and lipid-depleted fetal bovine serum (FBS) was from ThermoFisher Scientific. Trypan blue stain $(0.4 \%)$ for the usage together with a hemocytometer, trypsin-EDTA solution, cholesterol (>99\%), FBS, streptomycin/penstrip, phosphate buffer solution, thiazolyl blue tetrazolium bromide (MTT) were all from Sigma Aldrich, Unites States of America. 25hydroxycholesterol was from Cayman Chemical, US and BODIPY ${ }^{\circledR}$ FL LDL was from Invitrogen, US.

\subsection{Assay of 2, 2'-diphenyl-1-picrylhydrazyl (DPPH)}

Antioxidant activity was evaluated using 2, 2'diphenyl-1-picrylhydrazyl (DPPH) as described by Ramli et al. (2008), with some modifications. DPPH stock solution was prepared by dissolving $2.37 \mathrm{mg}$ of DPPH powder in $100 \mathrm{~mL}$ absolute $(100 \%)$ methanol. Black seed and honey mixtures stock solution were prepared with dimethyl sulfoxide (DMSO) to the concentration of $10 \mathrm{mM}$, respectively together with quercetin as the positive control. The solutions were loaded into a 96-well plate with performed serial dilution. Negative control was purely DMSO without test material. DPPH stock solution of $200 \mu \mathrm{L}$ was applied to each treated well and incubated for 30 minutes in dark. The absorbance of the mixture was read at $517 \mathrm{~nm}$ using an ELISA microplate reader. The percentage of the DPPH free radical activity was calculated using the following equation:

\section{DPPH scavenging effect $(\%)=\left[\left(\mathrm{A}_{0}-\mathrm{A}_{1}\right) / \mathrm{A}_{0}\right] \times 100$}

Where $A_{0}$ was the absorbance of the control and $A_{1}$ was the absorbance in the presence of the extracts. The $\mathrm{EC}_{50}$ (concentration providing $50 \%$ inhibition) values were calculated using the dose inhibition curve in the linear range by plotting the extract concentration versus the corresponding scavenging effect.

\subsection{Cell viability study}

Cell viability was examined using MTT cell assay. The cell density of $1.0 \times 10^{4}$ per well was seeded in a 96 well plate and grown to confluence. Ratio concentrations of black seed and honey mixture 1:0, 0:1, 1:1, 2:1 and 1:2 were prepared and administered to cells. Cells were incubated for $16 \mathrm{hrs}$ at $37^{\circ} \mathrm{C}$ with $5 \% \mathrm{CO}_{2}$.

\subsection{Low-density lipoprotein- cholesterol intake (LDL-c)}

Confluent cultures were seeded after applying trypsin for 4 mins. Cells were then seeded at $1.0 \times 10^{4}$ cells per well per $100 \mu \mathrm{L}$ culture medium in 96 well plates and allowed to grow until confluent. To study the effect of black seed and honey mixture on the LDL-c uptake in HepG2 cells, HepG2 cells were treated with EMEM complete medium, $0.05 \%$ lipid depleted FBS, 10 $\mu \mathrm{g} / \mathrm{mL}$ cholesterol, $1 \mu \mathrm{g} / \mathrm{mL} 25$-hydroxycholesterol with different ratios of black seed: honey $(1: 0,0: 1,1: 1,1: 2$, 2:1).

To study the effect of black seed and honey mixture combinations at different ratios of $(1: 0,0: 1,1: 1,2: 1,1: 2)$ and incubated for $16 \mathrm{hrs}$. All groups of cells were in quadruplets. Varioskan fluorescent plate reader was used to read the plate at 490 and $515 \mathrm{~nm}$ (Ishikawa et al., 2015)

\subsection{Statistical analysis}

Data were expressed as mean and standard deviation, of multiple determinations performed using black seed and honey mixtures derived from different concentrations with Minitab software version 14.0. Oneway ANOVA was conducted and multiple comparison analysis was carried out using Fisher's LSD test. In all analyses, if $\mathrm{p}<0.05$, the difference was considered significant.

\section{Results and discussion}

In the present study, the antioxidant of black seed and honey extracts mixtures with different ratios were performed to determine the best free scavenging activity through DPPH reduction. Table 1 shows the trends indicated with the increased sample concentration subsequently increased the scavenging effects on DPPH radical. The efficiency concentration of black seed and honey mixtures to inhibit $50 \% \mathrm{DPPH}$ radical $\left(\mathrm{EC}_{50}\right)$ is shown in Table 2. The $\mathrm{EC}_{50}$ is a parameter used to quantify antioxidant activity, with a lower value suggesting higher antioxidant potency. Among the treatments, the sample with black seed extract showed the highest DPPH reduction percentage while the sample with honey extract alone showed the lowest DPPH reduction percentage (Table 1) as shown with their $\mathrm{EC}_{50}$ value in Table 2. Thus, it can be observed that the antioxidant properties in the mixtures were mostly due to the antioxidant activity in black seed extract and can be suggested that there might be no synergistic effect between the black seed extract and honey extract samples.

Quercetin is a polyphenolic flavonoid compound that is commonly present in plants and plant food resources. It is a good natural antioxidant because of its ability to scavenge free radicals and bind transition metal ions (Baghel et al., 2012). Thus, in the present study, quercetin was selected as a positive control for the antioxidant assay. Mohamad et al. (2014) reported that 
Table 1. DPPH Inhibition by black seed and honey mixture

\begin{tabular}{ccccccc}
\hline \multirow{2}{*}{ Concentration $(\mathrm{mg} / \mathrm{mL})$} & \multicolumn{7}{c}{ \% of DPPH Reduction } \\
\cline { 2 - 7 } & $\mathrm{B}$ & $\mathrm{H}$ & BH & BBH & BHH & Q \\
\hline 0 & 0 & 0 & 0 & 0 & 0 & 0 \\
0.156 & $2.19(0.69)^{\mathrm{c}}$ & $1.15(0.52)^{\mathrm{c}}$ & $1.31(0.27)^{\mathrm{c}}$ & $7.32(1.00)^{\mathrm{b}}$ & $2.56(1.02)^{\mathrm{c}}$ & $15.25(4.59)^{\mathrm{a}}$ \\
0.313 & $4.15(0.84)^{\mathrm{c}}$ & $2.09(0.28)^{\mathrm{c}}$ & $3.47(1.43)^{\mathrm{c}}$ & $7.71(0.60)^{\mathrm{b}}$ & $7.02(0.81)^{\mathrm{b}}$ & $30.05(1.66)^{\mathrm{a}}$ \\
0.625 & $13.43(4.29)^{\mathrm{b}}$ & $4.39(0.36)^{\mathrm{c}}$ & $6.75(1.66)^{\mathrm{c}}$ & $15.79(1.90)^{\mathrm{b}}$ & $9.04(1.02)^{\mathrm{bc}}$ & $68.62(8.22)^{\mathrm{a}}$ \\
1.25 & $16.00(3.83)^{\mathrm{c}}$ & $8.10(0.54)^{\mathrm{d}}$ & $15.97(3.04)^{\mathrm{c}}$ & $21.37(2.65)^{\mathrm{b}}$ & $12.53(1.40)^{\mathrm{c}}$ & $96.81(0.61)^{\mathrm{a}}$ \\
2.5 & $34.24(5.06)^{\mathrm{b}}$ & $12.42(1.42)^{\mathrm{d}}$ & $23.75(4.83)^{\mathrm{c}}$ & $25.91(3.04)^{\mathrm{c}}$ & $14.13(1.35)^{\mathrm{d}}$ & $97.93(0.56)^{\mathrm{a}}$ \\
5 & $40.25(1.85)^{\mathrm{c}}$ & $28.68(2.00)^{\mathrm{e}}$ & $38.80(2.77)^{\mathrm{c}}$ & $45.04(5.10)^{\mathrm{b}}$ & $31.31(4.29)^{\mathrm{d}}$ & $97.98(0.58)^{\mathrm{a}}$ \\
10 & $72.13(3.65)^{\mathrm{b}}$ & $51.38(1.87)^{\mathrm{d}}$ & $57.02(2.97)^{\mathrm{c}}$ & $59.28(1.87)^{\mathrm{c}}$ & $56.79(3.16)^{\mathrm{c}}$ & $98.42(0.48)^{\mathrm{a}}$ \\
\hline
\end{tabular}

Values are presented as mean(SD) from quadruplicate. Values with different superscript within the same row indicate significant difference $(\mathrm{p}<0.05)$ by one-way ANOVA.

$\mathrm{B}=$ Black seed, $\mathrm{H}=$ Honey, $\mathrm{BH}=$ mixture of black seed and honey with the ratio $1: 1, \mathrm{BBH}=$ mixture of black seed and honey with the ratio $2: 1, \mathrm{BHH}=$ mixture of black seed and honey with the ratio $1: 2, \mathrm{Q}=$ Quercetin

the mixture of black seed and honey exhibited the highest lipid-soluble antioxidant capacity as compared to either black seed or honey alone. This is in contrast with the result of the present finding. However, there are probabilities where a higher concentration of black seed and honey mixtures show a synergistic effect with a higher percentage of DPPH reduction. The $\mathrm{EC}_{50}$ value for the honey sample extract of the present study was $9.56 \mathrm{mg} / \mathrm{mL}$ which falls in the range of $\mathrm{EC}_{50}$ value of other studies whereby the Indian honey samples had the $\mathrm{IC}_{50}$ values of antioxidant ranging between 4.5 to 66.1 $\mathrm{mg} / \mathrm{mL}$ (Reshma et al., 2016). $\mathrm{EC}_{50}$ of black seed extract in the present study was lower as compared to the previous study. A previous study reported that black seed extract with different types of extraction methods showed $\mathrm{IC}_{50}$ in the range of 1.07 to $4.48 \mathrm{mg} / \mathrm{mL}$ for DPPH antioxidant assay (Meziti et al., 2012). Chloroform extract and ethyl acetate extract showed the best radical scavenging activity. The scavenging is most likely due to their high phenolic and flavonoid content such as carvacrol, t-antherol, 4-terpineol and thymoquinone (Meziti et al., 2012).

Table 2. $\mathrm{EC}_{50}$ of black seed and honey mixtures

\begin{tabular}{cc}
\hline Treatment & $\mathrm{EC}_{50}(\mathrm{mg} / \mathrm{mL})$ \\
\hline $\mathrm{B}$ & 6.54 \\
$\mathrm{H}$ & 9.56 \\
$\mathrm{BH}$ & 7.97 \\
$\mathrm{BBH}$ & 7.34 \\
$\mathrm{BHH}$ & 8.67 \\
$\mathrm{Q}$ & 0.76 \\
\hline
\end{tabular}

$\mathrm{B}=$ Black seed, $\mathrm{H}=$ Honey, $\mathrm{BH}=$ mixture of black seed and honey with the ratio $1: 1, \mathrm{BBH}=$ mixture of black seed and honey with the ratio $2: 1, \mathrm{BHH}=$ mixture of black seed and honey with the ratio $1: 2, \mathrm{Q}=$ Quercetin

Lower antioxidant activity can be seen in the present study due to the aqueous extraction of black seed used in this study, which may lead to lower phenolic and flavonoid content. Besides, Islam et al. (2012) reported that black seed extract had an $\mathrm{IC}_{50}$ value of 0.16 to 1.03 $\mathrm{mg} / \mathrm{mL}$ in DPPH radical scavenging activity using different extraction methods, including essential oil, methanol extract, hexane extract, chloroform extract and ethyl acetate extract. The black seed essential oil displayed the lowest $\mathrm{IC}_{50}$ value at $12.76 \mu \mathrm{g} / \mathrm{mL}$ compared to another method of extraction. This is because 24 constituents have been identified in the black seed oil, although only 16 components have been identified in the extracts. It was confirmed that the black seed oil had the highest and the strongest radical scavenging activity compared to the extracts. Meanwhile, Haron et al. (2014) determined the antioxidant activity of black seeds of different origins by DPPH inhibition. They reported that black seed from Iran had the lowest $\mathrm{IC}_{50}$ of $1.49 \mathrm{mg} / \mathrm{mL}$ followed by black seed from Kelantan with $\mathrm{IC}_{50}$ of $1.79 \mathrm{mg} / \mathrm{mL}$. The $\mathrm{IC}_{50}$ obtained in the present study was higher than the previous research suggesting a lower antioxidant activity in the samples used. Differences may be due to the method of extraction used in which the black seed was extracted by aqueous extraction in the present study, which may lead to lower phenolic and flavonoid contents of the extract, whereas the methanol extract and black seed oil were used in the previous study. The difference in antioxidant activity values may also be attributable to the different origins of the black seed. As shown in the previous report, local black seed (Kelantan black seed) has lower antioxidant activity than foreign black seed (Iran) as a proportion of its total phenolic content. The extraction method can also affect the antioxidant activity by which oil extraction has the highest antioxidant activity compared to other extraction solvents (chloroform and ethyl acetate) whereas the aqueous extract showed the lowest (Haron et al., 2014). The low antioxidant activity of the aqueous black seed extract was also proven in the present study.

Based on Table 3, it was observed that all ratios 
Table 3. Cell viability of black seed and honey mixtures at different ratios

\begin{tabular}{cccccc}
\hline \multirow{2}{*}{ Concentration $(\mathrm{mg} / \mathrm{mL})$} & \multicolumn{5}{c}{ Percentage of Cells Viability $(\%)$} \\
\cline { 2 - 6 } & $\mathrm{B}$ & $\mathrm{H}$ & $\mathrm{BH}$ & $\mathrm{BBH}$ & BHH \\
\hline 0 & 100 & 100 & 100 & 100 & 100 \\
1.562 & $65.27(5.43)^{\mathrm{b}}$ & $76.37(0.22)^{\mathrm{a}}$ & $64.92(1.07)^{\mathrm{b}}$ & $80.63(0.49)^{\mathrm{a}}$ & $66.93(0.41)^{\mathrm{b}}$ \\
3.125 & $65.97(8.67)^{\mathrm{a}}$ & $72.26(2.36)^{\mathrm{a}}$ & $63.88(0.81)^{\mathrm{b}}$ & $74.57(2.20)^{\mathrm{a}}$ & $65.68(0.33)^{\mathrm{b}}$ \\
6.25 & $63.06(7.29)^{\mathrm{ab}}$ & $67.64(2.14)^{\mathrm{a}}$ & $57.77(0.11)^{\mathrm{b}}$ & $64.98(3.69)^{\mathrm{a}}$ & $60.32(2.17)^{\mathrm{ab}}$ \\
12.5 & $46.55(3.45)^{\mathrm{b}}$ & $65.54(5.09)^{\mathrm{a}}$ & $40.44(5.23)^{\mathrm{c}}$ & $45.68(2.23)^{\mathrm{c}}$ & $53.46(6.12)^{\mathrm{b}}$ \\
25 & $19.23(3.57)^{\mathrm{d}}$ & $52.82(0.31)^{\mathrm{a}}$ & $31.78(3.01)^{\mathrm{c}}$ & $37.72(0.48)^{\mathrm{b}}$ & $36.94(4.30)^{\mathrm{b}}$ \\
50 & $6.12(0.66)^{\mathrm{d}}$ & $41.75(6.31)^{\mathrm{a}}$ & $6.51(0.42)^{\mathrm{d}}$ & $19.22(4.92)^{\mathrm{c}}$ & $35.10(1.05)^{\mathrm{b}}$ \\
100 & $5.15(0.13)^{\mathrm{c}}$ & $37.80(1.27)^{\mathrm{a}}$ & $3.45(0.10)^{\mathrm{d}}$ & $5.57(0.11)^{\mathrm{c}}$ & $32.87(0.33)^{\mathrm{b}}$ \\
\hline
\end{tabular}

Values are presented as mean(SD) from quadruplicate. Values with different superscript within the same row indicate significant difference $(\mathrm{p}<0.05)$ by one-way ANOVA.

$\mathrm{B}=$ Black seed, $\mathrm{H}=$ Honey, $\mathrm{BH}=$ mixture of black seed and honey with the ratio $1: 1, \mathrm{BBH}=$ mixture of black seed and honey with the ratio $2: 1, \mathrm{BHH}=$ mixture of black seed and honey with the ratio 1:2.

lowered the HepG2 cell viability on a dose-dependent pattern. Among all treatments, the mixture of black seed and honey with a 1:1 ratio showed the significantly $(p<0.05)$ lowest percentage of cell viability $(3.45 \%)$ at the highest concentration, $100 \mu \mathrm{g} / \mathrm{mL}$. The lowest cell viability might be due to the synergistic effect of both black seed extract and honey extract at 1:1 ratio, but not at $2: 1$ or $1: 2$ ratio mixture. However, the effect of the black seed and honey mixture of 1:1 ratio was most probably contributed by the potential of black seed which was shown by the lowest percentage of cell viability of black seed extract at $50 \mu \mathrm{g} / \mathrm{mL}$.

Table 4 shows that black seed extracts possessed the most potent anticancer activity against $\mathrm{HepG} 2$ cells $\left(\mathrm{IC}_{50}\right.$ value $7.62 \mu \mathrm{g} / \mathrm{mL}$ ) while honey extracts possessed the lowest $\mathrm{IC}_{50}$ value $31.10 \mu \mathrm{g} / \mathrm{mL}$. All treatments were ideal anti-cancer agents with $\mathrm{IC}_{50}$ values of less than $20 \mu \mathrm{g} / \mathrm{mL}$ except for the treatment with honey extract alone with the moderate cytotoxic activity of $\mathrm{IC}_{50}$ values between 20 to $100 \mu \mathrm{g} / \mathrm{mL}$ (Sajjadi et al., 2015). In general, the anticancer effect of black seed and honey mixtures could be due to the anti-cancer properties of black seed instead of honey, particularly at a lower concentration. In general, the anticancer effect of black seed and honey mixtures could be due to the anti-cancer properties of black seed instead of honey, particularly at lower concentrations. However, there was a possibility that black seed and honey mixture 1:1 ratio to show the synergistic effect at a higher concentration since the mixture showed a significant reduction of cell viability starting from $12.5 \mu \mathrm{g} / \mathrm{mL}$.

According to Hassan et al. (2012), treatment of HepG2 cells with the black seed at the highest concentration of $5000 \mu \mathrm{g} / \mathrm{mL}$ reduced the survival rate of HepG2 cells by $37.8 \%$ after $72 \mathrm{hrs}$ of treatment which had a lower effect as compared to the present study. In the present study, black seed showed a higher reduction of cell viability at a lower concentration $(100 \mu \mathrm{g} / \mathrm{mL})$ of extracts and a shorter treatment period ( $24 \mathrm{hrs})$. This is due to the different types of black seed as the black seed used in the previous study was from Egypt. For honey, a previous study showed that Gelam honey exerted high cytotoxic on HepG2 cells and human hepatic cells (WRL -68). Gelam honey reduced the cell viability of HepG2 less effectively by showing $\mathrm{IC}_{50}$ at $25 \% \mathrm{w} / \mathrm{v}$ of $31.10 \mu \mathrm{g} /$ $\mathrm{mL}$ which is equivalent to $0.0031 \% \mathrm{w} / \mathrm{v}$. This proved that Gelam honey exhibited growth inhibition at higher concentrations and was less sensitive in HepG2 cells as compared to the current honey sample.

Table 4. Summary of $\mathrm{IC}_{50}$ value of black seed and honey mixtures against HepG2 Cells

\begin{tabular}{cc}
\hline Treatment & $\mathrm{IC}_{50}(\mu \mathrm{g} / \mathrm{mL})$ \\
\hline B (Black Seed: Honey - 1:0) & 7.62 \\
H (Black Seed: Honey - 0:1) & 31.10 \\
BH (Black Seed: Honey - 1:1) & 7.44 \\
BBH (Black Seed: Honey - 2:1) & 10.98 \\
BHH (Black Seed: Honey - 1:2) & 15.23 \\
\hline
\end{tabular}

$\mathrm{IC}_{50}<20 \mu \mathrm{g} / \mathrm{mL}=$ highly cytotoxicity, $\mathrm{IC}_{50} 21-200 \mu \mathrm{g} / \mathrm{mL}=$ moderately cytotoxicity, $\mathrm{IC}_{50} 201-500 \mu \mathrm{g} / \mathrm{mL}=$ weakly cytotoxicity, $\mathrm{IC}_{50}>501 \mu \mathrm{g} / \mathrm{mL}=$ no cytotoxicity.

In the present study, black seed showed a higher antioxidant scavenging effect and cytotoxicity towards HepG2 cells as compared to honey. Although the black seed and honey mixtures did not show the potential of synergistic effect in antioxidant activity, there might be a synergistic effect on the HepG2 cells cytotoxicity. Thus, the cytotoxicity effect might not be attributable to antioxidant properties but due to other mechanisms not explored in the present study. Apart from antioxidant compounds, the other pathways that could be responsible for reducing cell proliferation on HepG2 cells were p53 protein, cell cycle arrest, antimutagenic activity, estrogen modulation, anti-inflammatory activity, 
immunomodulatory activity, cyclooxygenase-2 (COX-2) modulation and tumour necrosis factor (TNF) modulation (Ahmed and Othman, 2013).

Figure 1 shows that the highest LDL uptake was exhibited by the black seed and honey mixture at ratio $1: 2$ with $294.4 \%$ at $15 \mu \mathrm{g} / \mathrm{mL}$ as compared to the positive control. This suggests that the black seed and honey mixture might gave a synergistic effect.

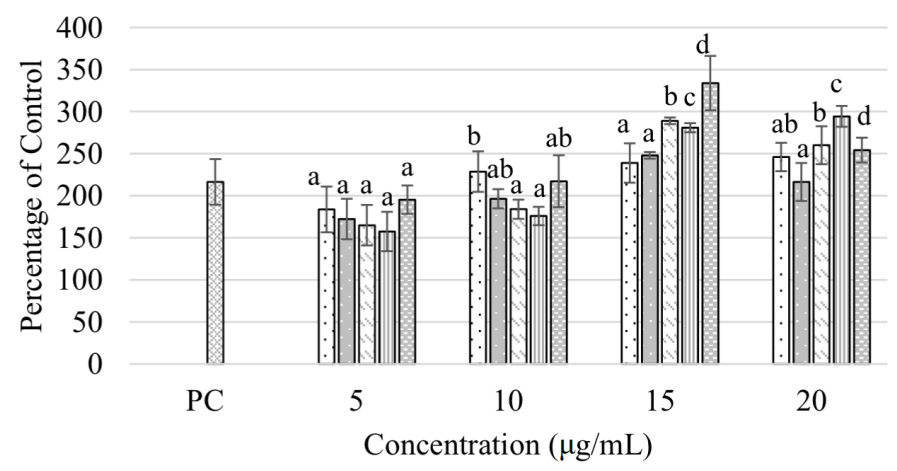

图Positive Control $\square \mathrm{B} \quad \square \mathrm{H} \quad \square \mathrm{BH} \square \mathrm{BBH} \square \mathrm{BHH}$

Figure 1. Effect of black seed and honey extracts mixtures on LDL-c uptake in HepG2 cells. Values are presented as mean (SD) from quadruplicate. Bars with the different notation within the same group indicate significant difference $(p<0.05)$ by one-way ANOVA.

$\mathrm{B}=$ Black seed, $\mathrm{H}=$ Honey, $\mathrm{BH}=$ mixture of black seed and honey with the ratio $1: 1, \mathrm{BBH}=$ mixture of black seed and honey with the ratio $2: 1, \mathrm{BHH}=$ mixture of black seed and honey with the ratio $1: 2$.

A previous study showed that black seed and honey mixture had significant benefits in hypercholesterolemic subjects as compared to healthy subjects. For hypercholesterolemic subjects, their total cholesterol, triglycerides, and the ratio of TC: HDL-c decreased significantly while HDL-c increased significantly; while there was also a decrease in LDL-c but not significantly (Mohamad et al., 2014). Thus, it shows that the result was correlated with the present study whereby the black seed and honey mixture showed a synergistic effect on cholesterol-lowering. El-Kholy et al. (2007) reported that rats with the treatment of black seed and honey mixture showed significant improvements in total lipids, total cholesterol, triglycerides, HDL-c and LDL-c as compared to the treatment of black seed and honey alone.

In the present study, black seed extract showed high LDL uptake $(246.0 \%)$ at $20 \mu \mathrm{g} / \mathrm{mL}$ while honey extract had LDL-c uptake by $248.0 \%$ at $15 \mu \mathrm{g} / \mathrm{mL}$. Previously, Ibrahim et al. (2014) found that menopausal women that were orally given one gram of black seed capsules daily for two months demonstrated significant improvement in total cholesterol, triglycerides, LDL-c, HDL-c and blood glucose although there were no significant changes in body weight. On the other hand, young healthy Pakistani males who received $70 \mathrm{~g}$ of honey every day for 4 weeks showed a significant decrease in total cholesterol and LDL level while HDL increases significantly. However, there were no significant changes in their blood glucose and triglyceride (Majid et al., 2013).

A thymoquinone-rich fraction from black seed was observed to induce LDL-c uptake through the upregulation of LDL receptor (LDLR) gene and inhibition of cholesterol synthesis through suppression of 3-hydroxy-3-methyl-glutaryl-coenzyme A reductase (HMGCR) gene in HepG2 cells more than thymoquinone. This suggests that the effect of the thymoquinone-rich fraction may be due to the combination of rich components in black seed (AlNaqeep et al., 2009). Besides, quercetin in honey increases the clearance of circulating LDL-c levels from the blood through up-regulation of LDLR gene expression at both mRNA and protein levels in HepG2 cells (Moon et al., 2012). Based on this study, it can be observed the lower antioxidant activity was due to the aqueous extraction method of black seed used which may contribute to lower phenolic and flavonoid content. However, since the LDL expression in the black seed and honey mixture was not parallel to antioxidant activity, there are possibilities that other mechanisms may contribute to LDL-c uptake in HepG2 cells. LDL-c uptake may be due to the down-regulation of proprotein convertase subtilisin/kexin type 9 (PCSK9) gene which was responsible for the degradation of LDLR in lysozyme and other lipoproteins metabolism-related gene expression includes sterol regulatory element-binding protein 2 (SREBP2) (Lagace, 2014).

\section{Conclusion}

The present study was the first research investigating the potential effect of black seed and honey extracts mixtures on lipid uptake in HepG2 cells. The black seed and honey mixture with a ratio of 1:2 was observed with the highest LDL-c uptake (294.4\%) at $15 \mu \mathrm{g} / \mathrm{mL}$. On the other hand, there was no possible synergistic effect on the antioxidant properties of the black seed and honey mixtures. This is proved by the highest $\mathrm{EC}_{50} 6.54 \mathrm{mg} / \mathrm{mL}$ in black seed extract as compared to other treatments. Since cancer cells, HepG2 cells were used in the present study for the determination of LDL-c uptake and antioxidant, the anticancer potential of black seed and honey mixtures were observed too. Black seed and honey mixtures with a ratio of 1:1 exhibited the strongest anticancer agent with an $\mathrm{IC}_{50}$ value of $7.44 \mu \mathrm{g} / \mathrm{mL}$ as compared to other treatments. In conclusion, high $\mathrm{EC}_{50}$ in antioxidants is not necessarily linked to high LDL-c uptake and high reduction of cell viability $\left(\mathrm{IC}_{50}\right)$. 
Therefore, it was suggested that there may be other mechanisms that lead to LDL uptake and reduction of cancer cell viability. The present study has demonstrated evidence on the hypocholesterolemic, antioxidant and anticancer potential of black seed and honey extracts mixtures.

\section{References}

Ahmed, S. and Othman, N.H. (2013). Honey as a potential natural anticancer agent: A review of its mechanisms. Evidence-Based Complementary and Alternative Medicine, 2013, 829070. https:// doi.org/10.1155/2013/829070

Al-Naqeep, G., Ismail, M. and Allaudin, Z. (2009). Regulation of low-density lipoprotein receptor and 3 -hydroxy-3-methylglutaryl coenzyme A reductase gene expression by thymoquinone-rich fraction and thymoquinone in HepG2 cells. Journal of Nutrigenetics and Nutrigenomics, 2 (4-5), 163-172. https://doi.org/10.1159/000227264

Asgary, S., Ghannadi, A., Dashti, G., Helalat, A., Sahebkar, A. and Najafi, S. (2013). Nigella sativa L. improves lipid profile and prevents atherosclerosis: Evidence from an experimental study on hypercholesterolemic rabbits. Journal of Functional Foods, 5(1), 228-234. https://doi.org/10.1016/ j.jff.2012.10.011

Baghel, S.S., Shrivastava, N., Baghel, R.S., Agrawal, P. and Rajput, S. (2012). Review of Quercetin: Antioxidant and Anticancer Properties. World Journal of Pharmacy and Pharmaceutical Sciences, 1(1), 146-160.

Bosetti, C., Micellota, S., Dal Maso, L., Talamini, R., Montella, M., Negri, E., Conti, E., Franceschi, S. and Vecchia, C.L. (2004). Food groups and risk of prostate cancer in Italy. International Journal of Cancer, 110(3), 424-428. https://doi.org/10.1002/ ijc. 20142

Donato M.T., Tolosa L. and Gómez-Lechón, M.J. (2015). Culture and Functional Characterization of Human Hepatoma HepG2 Cells. In Vinken M. and Rogiers V. (Eds). Protocols in In Vitro Hepatocyte Research. Methods in Molecular Biology (Methods and Protocols). Vol. 1250. New York: Humana Press. https://doi.org/10.1007/978-1-4939-2074-7_5

El-Kholy, W.M., Hassan, H.A. and Nour, S.E. (2007). The role of black seed and/or bees honey in modulating the heart disorder induced by food additives in male rats. Egyptian Journal of Hospital Medicine, 28(1), 327-341. https://doi.org/10.21608/ ejhm.2007.17664

Erejuwa, O.O., Sulaiman, S.A. and Wahab, M.S.A.
(2014). Effects of honey and its mechanisms of action on the development and progression of cancer. Molecule, 19(2), 2497-2522. https:// doi.org/10.3390/molecules19022497

Gheldof, N., Wang, X.H. and Engeseth, N.J. (2002). Identification and quantification of antioxidant components of honeys from various floral sources. Journal of Agricultural and Food Chemistry, 50(21), 5870-5877. https://doi.org/10.1021/jf0256135

Goldstein, J.L. and Brown, M.S. (2009). History of Discovery: The LDL Receptor. Arteriosclerosis, Thrombosis, and Vascular Biology, 29(4), 431-438. https://doi.org/10.1161/ATVBAHA.108.179564

Haron, H., Grace-Lynn, C. and Shahar, S. (2014). Comparison of physicochemical analysis and antioxidant activities of Nigella sativa seeds and oils from Yemen, Iran and Malaysia. Sains Malaysiana, 43(4), 535-542.

Hassan, M.I., Mabrouk, G.M., Shehata, H.H. and Aboelhussein, M.M. (2012). Antineoplastic effects of bee honey and Nigella sativa on hepatocellular carcinoma cells. Integrative Cancer Therapies, 11 (4), 354-363. https:// doi.org/10.1177/1534735410387422

Ibrahim, R.M., Hamdan, N.S., Ismail, M., Saini, S.M., Rashid, S.N.A., Latiff, L.A. and Mahmud, R. (2014). Protective effects of Nigella sativa on metabolic syndrome in menopausal women. Advanced Pharmaceutical Bulletin, 4(1), 29-33.

Ishikawa, T., Kobayashi, M., Yanagi, S., Kato, C., Takashima, R., Kobayashi, E., Hagiwara, K. and Ochiya, T. (2015). Human induced hepatic lineageoriented stem cells: Autonomous specification of human iPS cells toward hepatocyte-like cells without any exogenous differentiation factors. Public Library of Science One, 10(4), e0123193. https:// doi.org/10.1371/journal.pone.0123193

Islam, R., Hasan, N., Siddiqui, S.A., Rashid, M.A., Al Zaheri Mahmud, S.K., Safiur Rahman, M. and Rahman, A. (2012). The black Seed Nigella sativa Linnaeus: A Study of the Antioxidant Activity of the Essential Oil and Extracts. Journal of Nature Science and Sustainable Technology, 7(1), 103-111.

Koshak, A., Koshak, E. and Heinrich, M. (2017). Medicinal benefits of Nigella sativa in bronchial asthma: A literature review. Saudi Pharmaceutical Journal. King Saud University, 25(8), 1130-1136. https://doi.org/10.1016/j.jsps.2017.07.002

Lagace, T.A. (2014). PCSK9 and LDLR degradation: regulatory mechanisms in circulation and in cells. Current Opinion in Lipidology, 25(5), 387-393. https://doi.org/10.1097/MOL.0000000000000114 
Lorusso, D., Bria, E., Costantini A., Di Maio, M., Rosti, G. and Mancuso, A. (2017). Patients' perception of chemotherapy side effects: expectations, doctorpatient communication and impact on quality of life - an Italian survey. European Journal Cancer Care, 26(2), e12618. https://doi.org/10.1111/ecc.12618

Majid, M., Younis M.A., Naveed A.K., Shah, M.U., Azeem, Z. and Tirmizi, S.H. (2013). Effects of natural honey on blood glucose and lipid profile in young healthy Pakistani males. Journal of Ayub Medical Collage Abbottabad, 25(3-4), 44-7.

Meziti, A., Meziti, H., Boudiaf, K., Mustapha, B. and Bouriche, H. (2012). Polyphenolic profile and antioxidant activities of Nigella sativa seed extracts in vitro and in vivo. World Academy of Science, Engineering and Technology, 64(6), 24-32.

Mohamad, S., Ibrahim, N.H. and Yusof, H.M. (2014). Blood Pressure and Lipid Lowering Effects of Nigella sativa Seeds and Honey Mixture. IOSR Journal of Nursing and Health Science, 3(5), 89-96. https://doi.org/10.9790/1959-03518996

Mohtashami, R., Huseini, H.F., Heydari, M., Amini, M., Sadeqhi, Z., Ghaznavi, H. and Mehrzadi, S. (2015). Efficacy and safety of honey based formulation of Nigella sativa seed oil in functional dyspepsia: A double blind randomized controlled clinical trial. Journal of Ethnopharmacology, 175, 147-152. https://doi.org/10.1016/j.jep.2015.09.022

Moon, J., Lee, S.M., Do, H.J., Cho, Y., Chung, J.H. and Shin, M.J. (2012). Quercetin up-regulates LDL receptor expression in HepG2 cells. Phytotherapy Research, 26(11), 1688-1694. https:// doi.org/10.1002/ptr.4646

Ramli, S., Bunrathep, S., Tansaringkarn, T. and Ruangrungis, N. (2008). Screening for free radical scavenging activity from ethanolic extract of mimosaceous plants endemic to Thailand. Journal of Health Research, 22(2), 55-59.

Rashidmayvan, M., Mohammadshahi, M., Seyedian, S.S. and Haghighizadeh, M.H. (2019). The effect of Nigella sativa oil on serum levels of inflammatory markers, liver enzymes, lipid profile, insulin and fasting blood sugar in patients with non-alcoholic fatty liver. Journal of Diabetes and Metabolic Disorders, 18(2), 453-459. https://doi.org/10.1007/ s40200-019-00439-6

Reshma, M.V., Shyma, S., George T.M., Rishin, A.V., Ravi, K.C. and Shilu, L. (2016). Study on the physicochemical parameters, phenolic profile and antioxidant properties of Indian honey samples from extrafloral sources and multi floral sources. International Food Research Journal, 23(5), 20212028.
Sadeghi-Aliabadi, H., Hamzeh, J. and Mirian, M. (2015). Investigation of Astragalus honey and propolis extract's cytotoxic effect on two human cancer cell lines and their oncogen and proapoptotic gene expression profiles. Advanced Biomedical Research, 4, 42. https://doi.org/10.4103/2277-9175.151251

Sahebkar, A., Beccuti, G., Simental-Mendía, L.E., Nobili, V. and Bo, S. (2016). Nigella sativa (black seed) effects on plasma lipid concentrations in humans: A systematic review and meta-analysis of randomized placebo-controlled trials. Pharmacological Research, 106, 37-50. https:// doi.org/10.1016/j.phrs.2016.02.008

Sajjadi, S.E., Ghanadian, M., Haghighi, M. and Mouhebat, L. (2015). Cytotoxic effect of Cousinia verbascifolia Bunge against OVCAR-3 and HT-29 cancer cells. Journal of HerbMed Pharmacology, 4 (1), 15-19.

Saman, H., Khalil-ur, R., Zahoor-ul-hassan, D., Nazish, J., Mansoor, H., Zafar, I.K., Kafeel, A., Khalid, M. and Ehsan E.V. (2010). Cardioprotective effect of gemmotherapeutically treated withania somnifera against chemically induced myocardial injury. Pakistan Journal of Botany, 42(2), 1487-1499.

Shafiq, H., Ahmad, A., Masud, T. and Kaleem, M. (2014). Cardio-protective and anti-cancer therapeutic potential of Nigella sativa. Iranian Journal of Basic Medical Sciences, 17(12), 967-979.

Shinde, S., Chivate, N., Kulkarni, P. and Naikwade, N. (2013). Hypolipidemic activity of Psidium Guajava Linn leaves extracts in hyperlipidemic rats. International Journal of Pharmacy and Pharmaceutical Sciences, 5(1), 70-72.

Stewart, B.W. and Wild, C.P. (2015). World Cancer Report 2014. IARC Report. International Agency for Research on Cancer. Geneva, Switzerland: WHO Press.

Sultan, M.T., Butt, M.S., Karim, R., Ahmad, N., Ahmad, R.S. and Ahmad, W. (2015). Nigella sativa fixed and essential oil improves antioxidant status through modulation of antioxidant enzymes and immunity. Pakistan Journal of Pharmaceutical Sciences, 28(2), 589-95.

Wan Ghazali, W.S. and Mohamed, M. (2015). An OpenLabel Pilot Study to Assess Honey Supplementation in Improving Lipid Profiles among Chronic Smokers. Journal of Integrative Medicine and Therapy, 2(1), 5. https://doi.org/10.13188/23781343.1000005

Wang, X., Ouyang, Y., Liu, J., Zhu, M., Zhao, G., Bao, W. and Hu, F.B. (2014). Fruit and vegetable consumption and mortality from all causes, 
cardiovascular disease, and cancer: Systematic review and dose-response meta-analysis of prospective cohort studies. British Medical Journal, 349, g4490. https://doi.org/10.1136/bmj.g4490

Wilkinson, M.J., Laffin, L.J. and Davidson, M.H. (2014). Overcoming toxicity and side-effects of lipidlowering therapies. Best Practice and Research: Clinical Endocrinology and Metabolism, 28(3), 439452. https://doi.org/10.1016/j.beem.2014.01.006 